\title{
Listening an Armadillo/Wech Song, Some Notes about Armadillo's Maya Yucatec Symbolism
}

\author{
Michel Boccara* \\ CNRS, Le bourg de Lentillac, France
}

Submission: March 18, 2018; Published: May 31, 2018

*Corresponding author: Michel Boccara, CNRS, Le bourg de Lentillac, France, Email: michel.boccara1@orange.fr

Keywords: Armadillo; Wech song; Cooking; Play; Padre padrone; Melancholic; Pear food; Ancestor; Jewellery; Mischievous; Symbolism; Eggs; Soldiers; Animals

\section{Commentry}

Two versions of this popular yucatec song were collected by two yucatec writers: Jose Tec Poot and Gerardo Can Pat [1]. I will begin by giving the version of Gerardo Can Pat, who has not been published and is the more extent, with notes about the variations of Jose Tec Poot's text. After that I will make some comments about the relation between the ts'ul and the armadillo and give some details about a cooking recipe and a play. Let just say in introduction for the non Yucatec speaking people that the ts'ul is, at the time of the conquest, the Spanish people, but he is also a «padre-padrone » and a mythical ancestor. In contemporary time, he may design North American people.

\section{U k'ayil chan weech}

Song of the little armadillo

Collected and transcribed by Gerardo Can Pat (this song is sung in melancholic and monotonous tone but, unfortunately, the music has not been transcribed)

Chichan weche le a chan polo

Uyo'och oon yum ts'ul (bis)

Dzum-Dzi', Dzum-Dzi', Dzum-Dzi' [2]

Little armadillo, here is your little head

The avocado-pear food of father ts'ul

Dzum-Dzi', Dzum-Dzi', Dzum-Dzi' [3]

Chichan weche le a chan soolo'

U platon yum ts'ul (bis)

Dzum-Dzi', Dzum-Dzi', Dzum-Dzi'
Little armadillo, here is your little shell

The plate of father ts'ul [4]

Dzum-Dzi', Dzum-Dzi', Dzum-Dzi'

Refrain

Amara k'ankab amara bu'tun

Tii kalap k'ankab

Ku man chichan wech

Dzum-Dzi', Dzum-Dzi', Dzum-Dzi'

By the plains and the hills

In the rutted tracks

You go, little armadillo

Dzum-Dzi', Dzum-Dzi', Dzum-Dzi'

Chichan weche le a chan neho'

U xolte' yum ts'ul (bis)

Dzum-Dzi', Dzum-Dzi', Dzum-Dzi'

Little armadillo, here is your tail

The stick of father $t s^{\prime} u l$

Dzum-Dzi', Dzum-Dzi', Dzum-Dzi'

Chichan weche le a chan mo'olo

U trinchante ts'ul (bis)

Dzum-Dzi', Dzum-Dzi', Dzum-Dzi' 
Little armadillo, here is your little tail

The knife of father $t s^{\prime} u l$

Dzum-Dzi', Dzum-Dzi', Dzum-Dzi'

Refrain

Chichan weche le neek' a wicho'

Uyo'och p'aak yum ts'ul (bis)

Dzum-Dzi,' Dzum-Dzi', Dzum-Dzi'

Little armadillo, here is your eye's apple

The food tomato of father ts'ul

Dzum-Dzi', Dzum-Dzi', Dzum-Dzi'

Chichan weche le a chan xikimo'

U kuchara yum ts'ul (bis)

Dzum-Dzi', Dzum-Dzi', Dzum-Dzi'

Little armadillo, here is your little ear

The spoon of father $t s^{\prime} u l$

Dzum-Dzi', Dzum-Dzi', Dzum-Dzi'

Refrain

Chichan weche le a chan tamanilo

U toot xunan yum ts'ul (bis)

Dzum-Dzi', Dzum-Dzi', Dzum-Dzi'

Little armadillo, here is your little leaver

The tassel of father ts'ul's lady

Dzum-Dzi,' Dzum-Dzi,' Dzum-Dzi'

Chichan weche le a chan chochelo'

U kadena xunaan yum ts'ul (bis)

Dzum-Dzi', Dzum-Dzi', Dzum-Dzi'

Little armadillo, here is your little tripes

The chain of father ts'ul's lady

Dzum-Dzi', Dzum-Dzi', Dzum-Dzi'

Refrain

Chichan weche le a chan mololo'

U sortija xunaan yum ts'ul (bis)

Dzum-Dzi,' Dzum-Dzi,' Dzum-Dzi'

Little armadillo, here is your little anus

The ring of father ts'ul's lady

Dzum-Dzi', Dzum-Dzi', Dzum-Dzi'
Chichan weche le a chan ta'o

U yo'och sikil yum ts'ul (bis)

Dzum-Dzi', Dzum-Dzi', Dzum-Dzi'

Little armadillo, here is your little shit

The food pumpkin's seed of father $t s^{\prime} u l$

Dzum-Dzi', Dzum-Dzi', Dzum-Dzi'

Refrain

Chichan weche le a chan he'o

U yo'och tuk' yum ts'ul (bis)

Dzum-Dzi', Dzum-Dzi', Dzum-Dzi'

Little armadillo, here is your little eggs

The food coyol of father ts'ul

Dzum-Dzi', Dzum-Dzi', Dzum-Dzi'

Chichan weche le a chan xibilo

U k'oyo' koh yum ts'ul (bis)

Dzum-Dzi', Dzum-Dzi', Dzum-Dzi'

Little armadillo, here is your little penis

The tooth pick of father $t s^{\prime} u l$

Dzum-Dzi', Dzum-Dzi', Dzum-Dzi'

Refrain

Every part of the armadillo's body is detailed and refer to a ts'ul's feature. It could be a body part but also a peace of clothes, a tool, and, in case of the ts'ul 's lady, a jewellery... Why this symbolism? Was the armadillo a royal animal? We know that the Spanish, and English, name was composed because the Spanish compare the armadillo's shell to an armor. And as the Spanish soldiers wore armors, so armadillo and Spanish fit together. But this song seems more ancient that the Spanish conquest and we find symbolism of the armadillo or wech in the preconquest documents. In the Madrid codex, we found several figures of the armadillo, and some of them are in dual context, referring to the subterran and celestial nature of the animal [5].

The wech is still an appreciated even if its' better to tell after finishing what was the meat that your guest eats. As if the armadillo's nature was masked, in the order of the invisible and the mythical. But probably also the armadillo has to be interpreted in relation with the ts'ul's nature: apparently handsome and perfumed, he is inside and stinking and ugly. José Tec has a more univocal interpretation: the song's form is "constituted in a grotesque an buffoon meaning, it is very possible that to choose the wech as a joke's object in relation with the strangers (i.e the Spanish) is because this animal has a strong nauseating flavor". But Jose doesn't consider that, prepared in a proper way, the animal test very good and can be confused with the pig. 
This dialectic can be found in the origin's myth of another lady: the X-tabay, in which the good lady, uts kolel, when she dies, began to stick horribly as her counterpart, the sinner, $x$-keban, has an odor of sanctity. Some decades ago, an armadillo's game was played in the village of Tabi [6], in which I have a house, since 40 years. This game consist in burying the animal and let just his tail appear. And everybody try to take out the animal by the tail. It is not so easy but you can do it if you know the secret: ask to a young lady to piss around the tail!

We found in this little mischievous game.

a. The relation of the armadillo with the excrement and the sticky,

b. His double nature: very strong and easy to beat if you know how to do... As the ts'ul.

\section{References}

1. Gerardo Can Pat given to me his manuscript which was not published. He died in the eighty and I dedicated him this text. José Tec Poot's text has been published twice: first in the Boletín de la Escuela de Ciencias Antropológicas de la Universidad de Yucatán, año (1978) 28(5): 4548 and secondly in a compilation of his works, edited after his death,
Yáanul u paakat k'in, Teresa Pool Ix y Marianne Gabriel compiladoras, Merida, 2011.

2. José Tec write $K u$ ts'i, ku ts'i, ku t'si: "write, write, write...", this must refer to the nature of the $t s^{\prime} u l$, a kind of wise person, but, as Jose quote: "we believe that the words "ku ts'i, ku ts'i, ku ts'i", that the author translate "write, write, write..;" are the onomatopoeia of the sound that the armadillo make when he breathes.

3. As we say above, this is onomatopoeia, if we want to traduce, it will be something like: mature your writing...

4. In Jose Tec's version, in state of « the plate », we have «the suit».

5. Knorossov describe and traduce the two figures of the 103 a page of Madrid's Codex in those terms: First figure Description of the scene: a bee and a armadillo are inside a temple Translation: Own bees Itsamna, high lord Second figure Description of the scene: a bee with closed eyes and a armadillo are inside a temple Translation: Own bees Yum tsek [who threaten of death] (Yuri Knorossov, Compendio Xcarel de la escritura jeroglífica maya descifrada por Yuri V. Knórosov, vol. 3, Mexico, 1999) Eduard Selers indentify the two armadillo as alive and death and representing Itzamna, usually in saurian form and a mythical ancestor associated to heaven and underground words (Eduard Selers, Las imagines de animals en los manuscritos mexicanos y mayas, Mexico, 2004).

6. Citer le jeu cuisine et les deux petits films sur le tatou... associé aux textes. 